\title{
Clinical determination of the nutritional status of companion animals
}

\section{Avaliação clínica do estado nutricional de animais de companhia}

\author{
Andrei Kelliton Fabretti ${ }^{1 *}$; Lucas Alécio Gomes²; Daniella Aparecida Godoi \\ Kemper $^{3}$; Rafael Oliveira Chaves ${ }^{4}$; Bernardo Kemper ${ }^{5}$; Patrícia Mendes Pereira ${ }^{6}$
}

\section{Highlights:}

Weight variation is a useful marker of nutritional status in companion animals.

Muscle mass score is a useful marker of nutritional status and prognosis.

Body condition score is a useful marker of nutritional status and prognosis.

Body mass index can assist in determining prognosis.

\begin{abstract}
A well-nourished animal is predisposed to good quality of life, health and high longevity. On the other hand, malnourished animals are predisposed to higher morbidity and mortality rates, recurrent hospitalizations, longer hospitalization times, and high health care expenditures. Malnutrition is associated with metabolic alterations and systemic dysfunctions, such as immunosuppression, impaired healing, and loss of weight due to reduced muscle and adipose mass, in addition to worsening skin and coat appearance. Nutritional assessment quantifies not only malnutrition and overweight but also how much these deviations would influence a patient's prognosis. In addition, the identification of malnourished animals allows the performance of specific nutritional treatments, with consequent clinical improvement. There are several techniques to evaluate nutritional status (NS) in dogs and cats; however, because they are individually limited, it is highly recommended to incorporate different methods before completing each case assessment. This literature review gathered information on the techniques of NS assessment during clinical examination, including anamnesis and physical examination. The importance of the manuscript is justified by the lack of nutritional semiology of small animals in the literature. In summary, there are useful markers of NS in companion animals: weight variation, the muscle mass score (MMS) and the body condition score (BCS). Additionally, the BCS, MMS and body mass index (BMI) assist in determining prognosis.
\end{abstract}

Key words: Mortality. Nutritional assessment. Malnutrition.

\section{Resumo}

Um animal bem nutrido é tendenciado a boa qualidade de vida, saúde e alta longevidade. Por outro lado, o animal desnutrido é predisposto a maiores taxas de morbidade e mortalidade, internações recorrentes, maior tempo de hospitalização e elevados gastos com cuidados na saúde. A desnutrição está associada a alterações metabólicas e disfunções sistêmicas, como imunodepressão, comprometimento

\footnotetext{
1 Prof. Dr., Universidade Estadual de Londrina, UEL, Departamento de Clínicas Veterinárias, Departamento de Histologia e Universidade do Norte do Paraná, UNOPAR, Londrina, PR, Brasil. E-mail: akfabretti@gmail.com

2 Prof. Dr., UEL, Departamento de Clínicas Veterinárias, Londrina, PR, Brasil. E-mail: lucasalecio@gmail.com

3 Prof ${ }^{a}$ Dra $^{\mathrm{a}}$, UNOPAR, Londrina, PR, Brasil. E-mail: daniellagodoi@hotmail.com

4 Prof. Dr., Universidade Caxias do Sul, UCS, Caxias do Sul, RS, Brasil. E-mail: rafaelochaves@hotmail.com

5 Prof. Dr., UNOPAR, Londrina, PR, Brasil. E-mail: bkemper@bol.com.br

6 Prof ${ }^{a}$ Dra $^{\text {a }}$, UEL, Departamento de Clínicas Veterinárias, Londrina, PR, Brasil. E-mail: pmendes@uel.br

* Author for correspondence
} 
da cicatrização, perda de peso por redução da massa adiposa e muscular, além de piora no aspecto da pele e pelagem. A avaliação nutricional não só quantifica subnutrição e sobrepeso, como também o quanto esses desvios influenciariam o prognóstico de um paciente. Além disso, a identificação dos animais desnutridos permite a realização de tratamentos nutricionais específicos, com consequente melhoria clínica. Existem várias técnicas para avaliar o estado nutricional (EN) em cães e gatos, porém, por serem limitadas individualmente, é altamente recomendável a associação de diferentes métodos, antes da conclusão para um caso. Essa revisão de literatura reúne informações sobre as técnicas de avaliação do EN por exame clínico, incluindo anamnese e exame físico. A importância do manuscrito se justifica pela carência na literatura sobre semiologia nutricional de pequenos animais. Em síntese, são marcadores úteis do EN em animais de companhia: a variação de peso, o escore de massa muscular (EMM) e o escore de condição corporal (ECC). Auxiliam na determinação do prognóstico: o ECC, o EMM e o índice de massa corporal.

Palavras-chave: Mortalidade. Avaliação nutricional. Desnutrição.

\section{Introduction}

Nutrients are fundamental for body growth, tissue maintenance and health and are also used in biochemical reactions to provide energy for metabolism, reproductive performance and exercise (Case, Daristotle, Hayek, \& Raasch, 2011). Proper nutrition increases longevity and quality of life and maintains health; on the other hand, a nutritionally unbalanced diet predisposes patients to malnutrition, disease and worse prognosis (Rosa, Fabretti, Zanutto, \& Chaves, 2014; Fabretti et al., 2014). Another cause of malnutrition is systemic diseases that lead to poor appetite and increased catabolism (Gagne \& Wakshlag, 2015; Michel, 2015).

Malnutrition is the condition in which the supply of nutrients and energy is insufficient to meet the body's demand. It is associated with metabolic changes and systemic dysfunctions, such as immunodepression and impairment of healing capacity (Gagne \& Wakshlag, 2015). Over time, malnutrition evolves into changes in body composition, such as a reduction in fat and muscle mass, and worsens the appearance of the skin and coat (Saker \& Remillard, 2010; Gagne \& Wakshlag, 2015).

In veterinary and human medicine, approximately $50 \%$ of hospitalized patients are malnourished, and nutritional status (NS) usually worsens during hospitalization, especially in dogs and cats with critical illnesses (Mauldin \& Davidson, 2007;
Maicá \& Schweigert, 2008; Saker \& Remillard, 2010). In one study, malnutrition rates close to $60 \%$ were observed in 215 hospitalized dogs, and the severity of malnutrition was strongly associated with the severity of the underlying disease (Fabretti, Fonseca, Coelho, Silva, \& Pereira, 2015).

Additionally, malnourished patients (humans and animals) have a higher rate of nosocomial infections, serious illnesses, longer hospital stays, higher frequency of hospitalizations and increased mortality (Liu, Brown, \& Silverstein, 2012; Corbee \& Kerkhoven, 2014; Gagne \& Wakshlag, 2015; Romano, Heinze, Barber, Mason, \& Freeman, 2016). For example, a study of 101 cats showed that both malnutrition and obesity were associated with higher death rates (Finn, Freeman, Rush, \& Lee, 2010). In a survey of 45 dogs with sepsis, late onset of nutritional support was found to be associated with prolonged hospital stays, higher medical expenses and worse prognosis (Liu et al., 2012). Another study of $30 \mathrm{dogs}$ with parvovirus showed that early nutritional support provided clinical improvement and a higher survival rate compared to animals that remained deprived of food (Mohr et al., 2003). In a survey of 324 dogs with cancer (lymphoma and osteosarcoma), an association was found between malnutrition and lower survival (Romano et al., 2016). These data show the great correlation between deviations in NS with morbidity and the benefit that nutritional assistance provides for clinical and prognostic improvement (Mohr 
et al., 2003; Liu et al., 2012; Fabretti et al., 2014; Michel, 2015).

Nutritional assessment is the clinical process used to identify undernourished or overweight people or animals that would benefit from nutritional assistance (Maicá \& Schweigert, 2008; Michel, 2015, 2017). In veterinary medicine, it consists of the evaluation of the animal, the consumed diet, the food management and environmental factors (Baldwin et al., 2010; Freeman et al., 2011; Eirmann, 2016). In addition, this assessment helps to define the cause of NS deviations and to estimate the risk of the patient having a poor prognosis (Maicá \& Schweigert, 2008; Finn et al, 2010; Michel, 2015, 2017).

Nutritional assessment also allows the identification of animal who are currently well-nourished but are at risk of becoming malnourished, the potential complications resulting from malnutrition and the selection of the most appropriate type of nutritional assistance for each patient (Brunetto \& Carcioffi, 2015; Michel, 2015, 2017; Fabretti, Siqueira, Chaves, Camacho, \& Pereira, 2018).

This association between NS and clinical complications is called "nutritional risk". Thus, nutritional assessment is both a diagnostic and prognostic instrument (Finn et al., 2010; Michel, 2015, 2017). In addition, routine NS followup evaluates the effectiveness of nutritional support designed for weight correction (Maicá \& Schweigert, 2008; Michel, 2015).

Regarding clinical nutrition, the main failures in veterinary medicine occur in the evaluation and monitoring of patients' NS. In addition, the use of complementary tests to evaluate NS is not commonly employed (Chandler \& Gunn-Moore, 2004; Fabretti et al., 2018). As a result of these failures, the American Association of Animal Hospitals (AAHA) and the World Small Animal Veterinary Association (WSAVA) launched, in 2010 and 2011, respectively, guidelines to instruct and standardize the evaluation of the NS, classifying it as the 5th vital parameter; these guidelines emphasized that NS should be evaluated at each patient visit (Baldwin et al., 2010; Freeman et al., 2011).

It is recommended that NS be identified at the time of admission or up to 24 hours after admission to help define the prognosis and to ensure that appropriate nutritional interventions can be initiated early, if necessary, to prevent complications associated with malnutrition (Liu et al., 2012; Veado, 2015).

However, in both human and veterinary medicine, the classification of patients as well-nourished or malnourished remains subjective, with no welldefined cutoff limits to characterize NS (Maicá \& Schweigert, 2008; Eirmann, 2016; Michel, 2015, 2017). Thus, the classification is often based on the subjective interpretation of clinical case information (Fabretti et al., 2015; Michel, 2017). To circumvent these limitations, it is suggested that several methods of evaluating NS are used simultaneously (Maicá \& Schweigert, 2008; Eirmann, 2016).

Despite the nutritional assessment guidelines published by major world agencies and the fact that the clinical importance of recognizing malnutrition is well described in the literature, there is a lack of research on the subject (Vandendriessche, Picavet, $\&$ Hesta, 2017). Most studies on nutritional status assessment in companion animals focus on obesity, body condition score (BCS) for identification of obese animals and owners' perceptions of their animals' NS (Vandendriessche et al., 2017). The literature on methods of diagnosing malnutrition is less abundant and more fragmented.

In addition, many small animal nutrition books do not contain chapters on nutritional semiology, and even the books on internal medicine discuss this only briefly. The situation is aggravated by the fact that there is a deficiency in the teaching of nutrition in veterinary schools, indicated by European authors (Becvarova, Prochazka, Chandler, \& Meyer, 2017), and it is possible to observe the same context in our country. 
These facts are reflected in clinical care. A US study showed that only $34.5 \%$ of the appointments in veterinary clinics included questions about diet, and in $76 \%$, the questions were incomplete, and the information obtained was limited (MacMartin, Wheat, Coe, \& Adams, 2015). Another study showed that only $50 \%$ of veterinarians consider themselves prepared to answer pet owners' questions about nutrition (Bergler, Wechsung, Kienzle, Hoff, \& Dobenecker, 2016). Additionally, in one survey, only $22 \%$ of the animals treated at a Belgian veterinary school hospital between 2014 and 2015 received nutritional guidance (Vandendriessche et al., 2017). In the authors' experience, these numbers seem to be even lower in our region. These data allow us to conclude that there is still unpreparedness of veterinarians regarding the clinical nutrition of companion animals.

Given the above, this literature review aimed to gather current information from the literature on the various methods of evaluating NS in pets, from anamnesis to physical examination, with an emphasis on the diagnosis of malnutrition. As NS deviations influence prognosis, this classification helps to deduce the patient's clinical outcome, and this will be discussed throughout the text. The authors intend to disseminate the evaluation techniques of NS, previously found fragmented in several publications, in a single article aiming to facilitate and accelerate learning and the practical application of clinical nutrition in companion animals.

\section{Nutritional status assessment}

The identification of malnourished animals that require nutritional support is based on the patient's history and physical and laboratory findings (Brunetto \& Carcioffi, 2015; Veado, 2015; Michel, 2017). Indications of malnutrition in the history and physical examination are anorexia for 3-5 days, rapid weight loss (> 5\% within 5 days) or chronic weight loss of $10 \%$, without fluid loss, consumption of less than $85 \%$ of the energetic need for maintenance, loss of muscle mass, thinness, low body mass index (BMI) and poor appearance of the skin and coat (Brunetto \& Carcioffi, 2015; Veado, 2015; Kathrani, 2016).

It should be taken into consideration that nutritional assessment in critically ill patients is problematic due to interference of the disease or therapeutic with outcome measures, making interpretation difficult (Maicá \& Schweigert, 2008; Liu et al., 2012; Brunetto \& Carcioffi, 2015; Kathrani, 2016). In this type of patient, morphometric measures, such as body weight and BMI, may be altered due to changes in hydration status and effusions, making these measures less valid if considered as monitoring and prognostic parameters (Maicá \& Schweigert, 2008; Liu et al., 2012; Brunetto \& Carcioffi, 2015).

\section{Nutritional inquiry form}

The assessment begins with the nutritional inquiry form. Current and usual diets are defined in detail, including food trade name, manufacturer, presentation form (dry, moist or semi-moist), flavor, caloric density, amount and frequency of consumption (Delaney \& Fascetti, 2006; Freeman et al., 2011; Kathrani, 2016; Johnson \& Freeman, 2017; Coe, O'Connor, MacMartin, Verbrugghe, \& Janke, 2020). The same is true for snacks, supplements and chewable toys (Michel, 2009; Freeman et al., 2011; Purina, 2016; Coe et al., 2020). If there has been a recent change in diet, it is important to question the time when it occurred (Baldwin et al., 2010; Freeman et al., 2011; Michel, 2009, 2017).

If the animal receives homemade food, we should inquire about the recipe, amount of all ingredients and preparation (Michel, 2009, 2013; Baldwin et al., 2010; Freeman et al., 2011; Johnson \& Freeman, 2017). The calorie density of homemade foods can be accessed on labels or on websites such as the 
US Department of Agriculture's National Nutrient Database (http://ndb.nal.usda.gov/ndb/search). If the recipe is not consistent, it is recommended to request a record of all foods provided within the last five to seven days (Michel, 2009).

Regarding food management, we should collect information about how food is used in interactions between the animal and other household members; sometimes, for example, it is used as a reward for good behavior or for performing tricks (Brooks et al., 2014; Eirmann, 2016).

It is also necessary to define mealtimes, place and method of feeding, whether meals are supervised and how many people are responsible for the animal's nutrition. In addition, we must record the form and place of storage of the food (Delaney \& Fascetti, 2006; Baldwin et al., 2010; Freeman et al., 2011; Michel, 2013).

Regarding the environment, the space where the animal lives (inside or outside the house), the presence of other pets and whether the animal is supervised or remains alone should be analyzed (Michel, 2009; Baldwin et al., 2010; Freeman et al., 2011; Purina, 2016). If there are other pets, it should be defined whether the food is provided individually or jointly, if there is competition for food or if the patient has access to food from humans, other animals or game (Michel, 2009, 2013; Eirmann, 2016; Purina, 2016). Additionally, it should be asked whether the patient leaves the property (Michel, 2009; Eirmann, 2016). Environmental factors, such as recent changes in routine, should also be noted (Baldwin et al., 2010; Freeman et al., 2011; Michel, 2017).

Regarding the patient, it is important to determine their age and physiological state. Very young, very old, pregnant and lactating animals are at increased risk for malnutrition (Baldwin et al., 2010; Freeman et al., 2011). We must record the physical activities that the animal performs, describing the type, frequency and quantity, as this will influence its energetic need (Michel, 2009; Baldwin et al., 2010; Freeman et al., 2011; Purina, 2016).

It is very important to define eating behavior and appetite level (Baldwin et al., 2010; Freeman et al., 2011; Michel, 2009, 2013, 2017). To do this, it is inquired if there are leftovers in the food bowl after the meal, if the animal selects the food it ingests, if it begs for food between meals or if it consumes other uncontrolled sources of food, such as the owners' meals (Michel, 2009, 2013). If the patient suffers from hyporexia or anorexia, the duration of these signs and the determining factors should be recorded whenever possible (Michel, 2009; Baldwin et al., 2010; Freeman et al., 2011; Kathrani, 2016; Johnson \& Freeman, 2017).

In addition, if the animal is sick, it is essential to determine the duration and evolution of the underlying disease, as well as if there are weight changes or if there are signs of gastrointestinal dysfunction, such as nausea, emesis, regurgitation, diarrhea, constipation, difficulty chewing or swallowing (Baldwin et al., 2010; Freeman et al., 2011; Purina, 2016; Kathrani, 2016). It is also important to record the medications or nutritional supplements used, as these can influence appetite, intestinal absorption of nutrients and metabolism (Mauldin \& Davidson, 2007; Michel, 2009; Eirmann, 2016; Purina, 2016).

All this information can be recorded on a nutritional inquiry form (Figure 1). The authors suggest that the form be made available for pet owners to fill in at home and then supplemented at the time of consultation. This would allow pet owners to access information on the diet and caloric density offered, important data that are often overlooked when reporting to the veterinarian during care. 
A

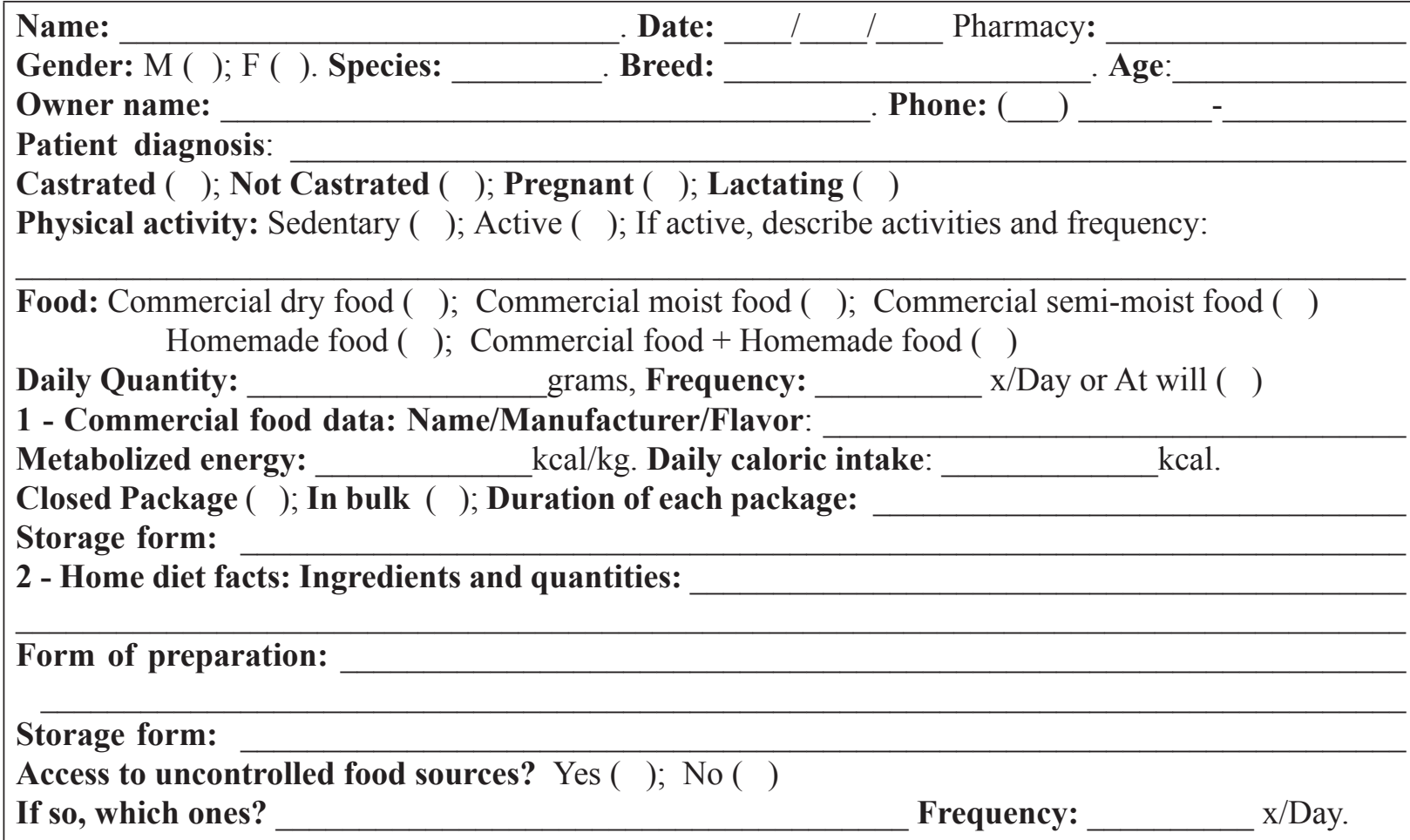

B

Snacks? Yes ( ); No ( ); If so, which ones?

Reason for use:

Daily quantity: $\quad$ grams, Frequency: ___ x/Day.

Supplements: Yes ( ); No ( ); If so, which ones?

Reason for use:

Daily quantity: _ grams or mL, Frequency: ___ x/Day.

Weight change? No ( ); Loss ( ); Gain ( ); Quantity?___ grams.

Since when?

Change in chewing/deglutition: Yes ( ); No ( ); Since when?

Appetite: Normal ( ); Increased ( ); Reduced ( ); Since when?

Diarrhea: Yes ( ); No ( ); Frequency: __ x/Day, Since when?

Vomiting: Yes ( ); No ( ); Frequency: _ _ x/Day, Since when?

Current diseases:

Previous diseases:

Medications in use:

Doses: _ $\quad \mathrm{mg} / \mathrm{kg}$; Administration routes:

Frequency: $\mathrm{x} /$ Day.

Environment: Inside the house ( ); Backyard ( ); Both ( ); Not domiciled ( )

Is food supervised? Yes ( ); No ( ); Number of treaters:

Are leftovers removed after meals? Yes ( ); No ( )

Joint meals with other animals: Yes $(\mathrm{)})$; No ( )

Is there competition between animals for food? Yes $(\quad)$; No $(\quad)$

Other information:

Figure 1. Pet Nutrition Inquiry Form. (A) Patient, owner and diet data. (B) Information on additional foods, health disorders and management. 


\section{Physical exam}

The physical effects of malnutrition can be subtle, variable and non-specific (Mauldin \& Davidson, 2007). When nutritional deficiency is in the early phases, it is usually subclinical, which makes the physical examination findings limited, making it impossible to use it as the only means of early diagnosis (Elliott, Ettinger, \& Feldman, 2010; Baldwin et al., 2010; Freeman et al., 2011).

The clinical signs most suggestive of malnutrition on clinical examination are weight loss (by fat or muscle mass), pale mucous membranes, recurrent infections, and abnormal nail growth. In advanced cases of hypoproteinemia, peripheral edema and effusions may form (Mauldin \& Davidson, 2007; Michel, 2015, 2017).

To confirm malnutrition, morphometry, which involves size measurements of various body sites, is widely used in human medicine (Maicá \& Schweigert, 2008). This technique is based on the knowledge that body proportions are related to total lean tissue, and increases can be explained by excessive fat accumulation (Maicá \& Schweigert, 2008; Santarossa, Parr, \& Verbrugghe, 2017). In other words, in humans, these physical examination steps measure lean and adipose body mass noninvasively, quickly, and without operating costs (Maicá \& Schweigert, 2008). These procedures are now better standardized for humans and cats than for dogs (Mawby et al., 2004; Santarossa et al., 2017).

In canines, the use of most morphometric techniques is problematic due to the large variation in physical size and body conformation between different breeds (Hesbach, 2007; Gama, Leite, Escodro, \& Notomi, 2016; Fabretti et al., 2018). However, some physical measurements, such as weight and BMI, are recommended and show good correlation with NS when interpreted together (Mauldin \& Davidson, 2007; Aptekmann, Mendes, Passo, Secchin, \& Galeas, 2014). These can even be evaluated by pet owners to monitor the NS of their animals (Aptekmann et al., 2014).
Body weight

Body weight assessment is an objective measure and is therefore associated with less variation between different examiners. Its routine use identifies early changes in NS (Bjornvad et al., 2011; Eirmann, 2016; Tarkosova, Story, Rand, \& Svoboda, 2016; Santarossa et al., 2017).

However, weight does not identify the most compromised body compartment, nor the etiology of the deviation or the moment of onset (Elliott et al., 2010; Eirmann, 2016). For example, the weight of hospitalized patients may be influenced by changes in hydration status, edema or effusions (Maicá \& Schweigert, 2008; Elliott et al., 2010). Therefore, it is recommended to use it in association with other measures (Maicá \& Schweigert, 2008; Aptekmann et al., 2014). Another limitation is that this variable is only altered in chronic nutritional deviations (Eirmann, 2016; Michel, 2017).

Malnutrition suggests a rapid ( $>5 \%$ in 1 month) or slow ( $>10 \%$ in 6 months) weight loss, with no change in hydration status (Maicá \& Schweigert, 2008; Brunetto \& Carcioffi, 2015; Veado, 2015).

\section{Body mass index}

BMI is an evaluation that uses morphometric measures to verify whether an individual's weight is proportional to his height and quantify deviations (Maicá \& Schweigert, 2008; Muller, Pinheiro, \& Mendonça, 2008). The greatest advantage of BMI is that it allows monitoring of NS with mathematical data, and it is not subject to subjective interpretations (Muller et al., 2008).

In 2008, a study involving 246 dogs of both sexes and different breeds established reference values and standardized a technique for measuring BMI in this species with the following formula (Muller et al., 2008):

$$
B M I=\frac{\text { Weight }(\mathrm{kg})}{[\text { Height }(\mathrm{m})]^{2}}
$$


Height is calculated with the aid of a flexible tape measure, measured from the base of the neck (atlanto-occipital joint), passing it over the spine and the medial portion to the iliac tuberosities, and supporting the tape over the base of the tail (last sacral vertebra) and posterior portion of a pelvic member to the ground (Muller et al., 2008).
For dogs weighing more than $25 \mathrm{~kg}$ or less than $10 \mathrm{~kg}$, mathematical adjustments must be made before interpreting NS by BMI. For dogs weighing > $25 \mathrm{~kg}$, subtract $20 \%$ from the calculated BMI value before using the table for interpretation. For dogs weighing $<10 \mathrm{~kg}$, add $10 \%$ of the calculated BMI value before using the table. After mathematical corrections, a BMI below 11.7 in dogs suggests malnutrition (Figure 2) (Muller et al., 2008).

\begin{tabular}{|c|c|c|}
\hline Underweight Suggestive & Ideal Weight Suggestive & Overweight Suggestive \\
\hline$<11.7$ & 11.8 a 15 & $>15$ \\
\hline
\end{tabular}

Figure 2. Interpretation of body mass index for dogs. Source: Muller et al., 2008.

Other researchers have proposed the following formula for dogs (Mawby et al., 2004):

$$
c B M I=\frac{\text { Weight }(\mathrm{kg})}{\text { Body Lenght }(\mathrm{cm}) \times \text { Height }(\mathrm{cm})}
$$

For this method, the length is the distance between the occipital protuberance to the base of the tail, and the height is the distance from the shoulder to the ventral surface of the thoracic limb (Mawby et al., 2004).

In cats, this formula has been described (Kawasumi, Iwazaki, Okada, \& Arai, 2016):

$$
f B M I=\frac{\text { Weight }(\mathrm{kg})}{\text { Body Lenght }(\mathrm{m}) \times \text { Height }(\mathrm{m})}
$$

In this calculation, the body length is the distance between the point of the shoulder and the tuber ischium, and the height is the distance from the point of the shoulder to the ventral aspect of the metacarpal pad (Kawasumi et al., 2016).

One study found a positive correlation between BMI and BCS in a study of 50 cats $(r=0.69 ; p$ $<0.0001$ ). The researchers concluded that BMI is a valid and simple technique for studying NS in this species. The formula used was weight $(\mathrm{kg}) /$ column length (m) (Aptekmann et al., 2014).
In general, the importance of this index is in its curvilinear relationship with morbidity and mortality, i.e., as BMI increases due to overweight, so would the risk for diseases associated with obesity, such as diabetes mellitus, lung disease, liver disease, hyperlipidosis, arthrosis, and wound healing complications (Muller et al., 2008; Fabretti et al., 2014). On the other hand, a lower BMI indicates a higher risk of malnutrition-related diseases, higher morbidity and mortality and reproductive disorders. That is, both extremes of BMI are associated with a higher risk of morbidity and mortality (Fabretti et al., 2014).

In 2015, a study evaluated the BMI of 215 hospitalized dogs and observed a reduction in values in patients with severe clinical malnutrition but not in patients with moderate or subclinical malnutrition; therefore, the authors suggested that a low BMI reinforces the diagnosis of malnutrition but does not allow its early identification (Fabretti et al., 2015). Another study evaluated the BMI and BCS of 30 Labrador retriever dogs and showed disagreement in the interpretation of these techniques in $46.7 \%$ of the cases (Gama et al., 2016). In summary, most studies show that the classification of NS based on BMI alone is not the best option because it does 
not reflect fat distribution and other factors, such as muscle or plasma volume, that affect this index directly (Muller et al., 2008; Fabretti et al., 2014, 2015; Gama et al., 2016).

For example, a high BMI could suggest obesity in thin individuals with hypertrophied muscles (Muller et al., 2008; Gama et al., 2016). In addition, in critically ill patients, weight may be significantly altered due to water volume depletion or overload (Liu et al., 2012; Brunetto \& Carcioffi, 2015). In accordance with the lack of specificity of BMI, some researchers consider it significant as an indicator of malnutrition only when its value is very low (Fabretti et al., 2015). It is noteworthy that WSAVA and the American Animal Hospital Association do not cite this method in their NS assessment guides (Baldwin et al., 2010; Freeman et al., 2011).

Even so, the ease of obtaining weight and height data, as well as its good correlation with morbidity and mortality, justify the use of BMI in epidemiological studies and clinical practice if associated with other methods that express fat composition and corporeal distribution (Aptekmann et al., 2014; Fabretti et al., 2014).

\section{Body condition score}

The BCS subjectively evaluates the amount of fat tissue in the hypodermis, allowing us to determine if the patient has weight deviation (Bjornvad et al., 2011; Eirmann, 2016; Michel, 2017). The fat mass represents the patient's energy stock (Elliott et al., 2010; Eirmann, 2016). For this classification, the fat covering of the ribs is evaluated by palpation, the waist is inspected from the dorsal view and abdominal thinning is inspected from the flanks (Laflamme, 1997a,b; Bjornvad et al., 2011; Tarkosova et al., 2016).

Qualifying the BCS of animals is free, easy to perform and reliable (Laflamme, 1997a; Witzel et al., 2014a,b). In addition, it can be taught to owners for realization and monitoring at home
(Laflamme, 1997a,b; Shoveller, Digennaro, Lanman, \& Spangler, 2014; Witzel et al., 2014a,b; Otsuji et al., 2016). The website of the Global Nutrition Committee of the World Association of Small Animals has a video to teach the technique (https://www.youtube.com/watch?v=tf_rwxqHYU\&amp=\&feature=youtu.be).

There are several methods of evaluating the BCS; all methods involve inspection and palpation of the aforementioned regions, but they have different scale scores (Santarossa et al., 2017). The most accepted classification is the nine-point scale, which was standardized and validated in 1997 using 255 healthy prepubescent adult dogs and 48 cats (Laflamme, 1997a,b; Tarkosova et al., 2016). This classification proved to be very well correlated with the adipose mass determined by double energy X-ray absorptiometry (DEXA) (Laflamme, 1997a,b; Bjornvad et al., 2011; Shoveller et al., 2014; Santarossa et al., 2017). Another recent study showed that this score was also well correlated to fat mass as observed by computed tomography (Kanda et al., 2013). In fact, the BCS is more correlated with the \% of body fat than with the patient's weight (Shoveller et al., 2014). An update of this system was performed in 2010 for dogs and cats (Purina, 2016).

The repeatability of this method, that is, the correlation between the same animal scores obtained in different evaluations by the same examiner, is 93\% (Laflamme, 1997a). Reproducibility, that is, the correlation between the scores of the same animal, obtained by different examiners, is $86 \%$ (Laflamme, 1997a). The predictability, i.e., the ability of the BCS to estimate the real body composition of the animal, is high and higher in females and obese animals (Laflamme, 1997a). This information supports the reliability of the BCS (Fabretti et al., 2015; Shoveller et al., 2014).

For dogs and cats, on the 9-point system, a score of 5 is ideal, with 4 being acceptable in dogs; lower scores suggest malnutrition, and higher scores 
indicate overweight/obesity (Figures 3, 4, and Aoyama, Morishita, Sugiyama, \& Otsuji, 2018; 5) (Laflamme, 1997a,b; Purina, 2016; Koizumi, Rollins \& Murphy, 2019).

\begin{tabular}{|c|c|c|c|}
\hline Score & Underweight Suggestive & Ideal Weight Suggestive & Overweight Suggestive \\
\hline Clinical \\
features & $\begin{array}{c}\text { Silhouette of ribs, lumbar ver- } \\
\text { tebrae and pelvic bones easily } \\
\text { noted on inspection or palpation } \\
\text { due to reduced fat mass on these } \\
\text { bones. Exaggerated abdomi- } \\
\text { nal retraction noted on lateral } \\
\text { inspection or ventral dorsum } \\
\text { (waist) }\end{array}$ & $\begin{array}{c}\text { Presence of adipose tissue in } \\
\text { small amount on ribs, identified } \\
\text { by palpation. It is not possible } \\
\text { to notice the silhouette of the } \\
\text { lumbar vertebrae on gentle in- } \\
\text { spection or palpation. Mild ab- } \\
\text { dominal retraction on inspection } \\
\text { (lateral and waist) }\end{array}$ & $\begin{array}{c}\text { Exaggerated layer of fat on ribs } \\
\text { making them hard to feel. It is } \\
\text { not possible to notice the silhou- } \\
\text { ette of the lumbar vertebrae. On } \\
\text { inspection (lateral and waist), } \\
\text { the abdominal retraction is very } \\
\text { discreet, nonexistent or the ab- } \\
\text { domen is distended. Fat may } \\
\text { accumulate at base of tail, limbs, } \\
\text { and neck }\end{array}$ \\
\hline
\end{tabular}

Figure 3. Interpretation of body condition score (grades 1-9) for companion animals.

Source: Laflamme (1997a,b) (Adapted).

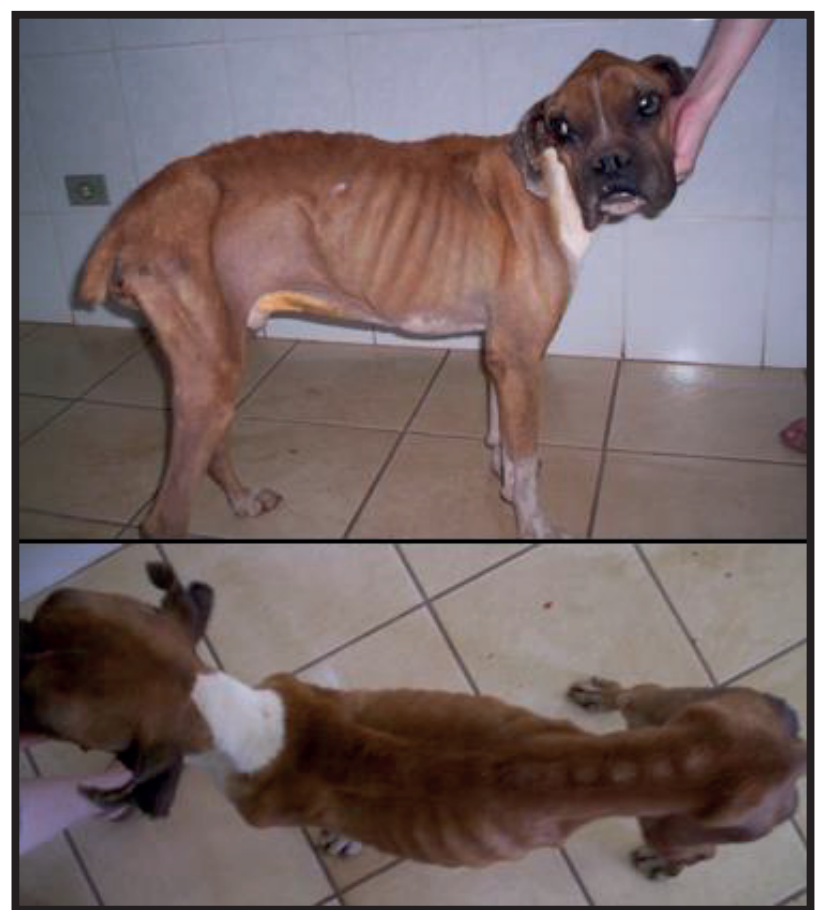

Figure 4. Body condition score in a thin boxer dog. Note the silhouette of the ribs, the top of the lumbar vertebrae and the exaggeratedly retracted waist. This animal was classified as score 1 (grade range: 1-9). 


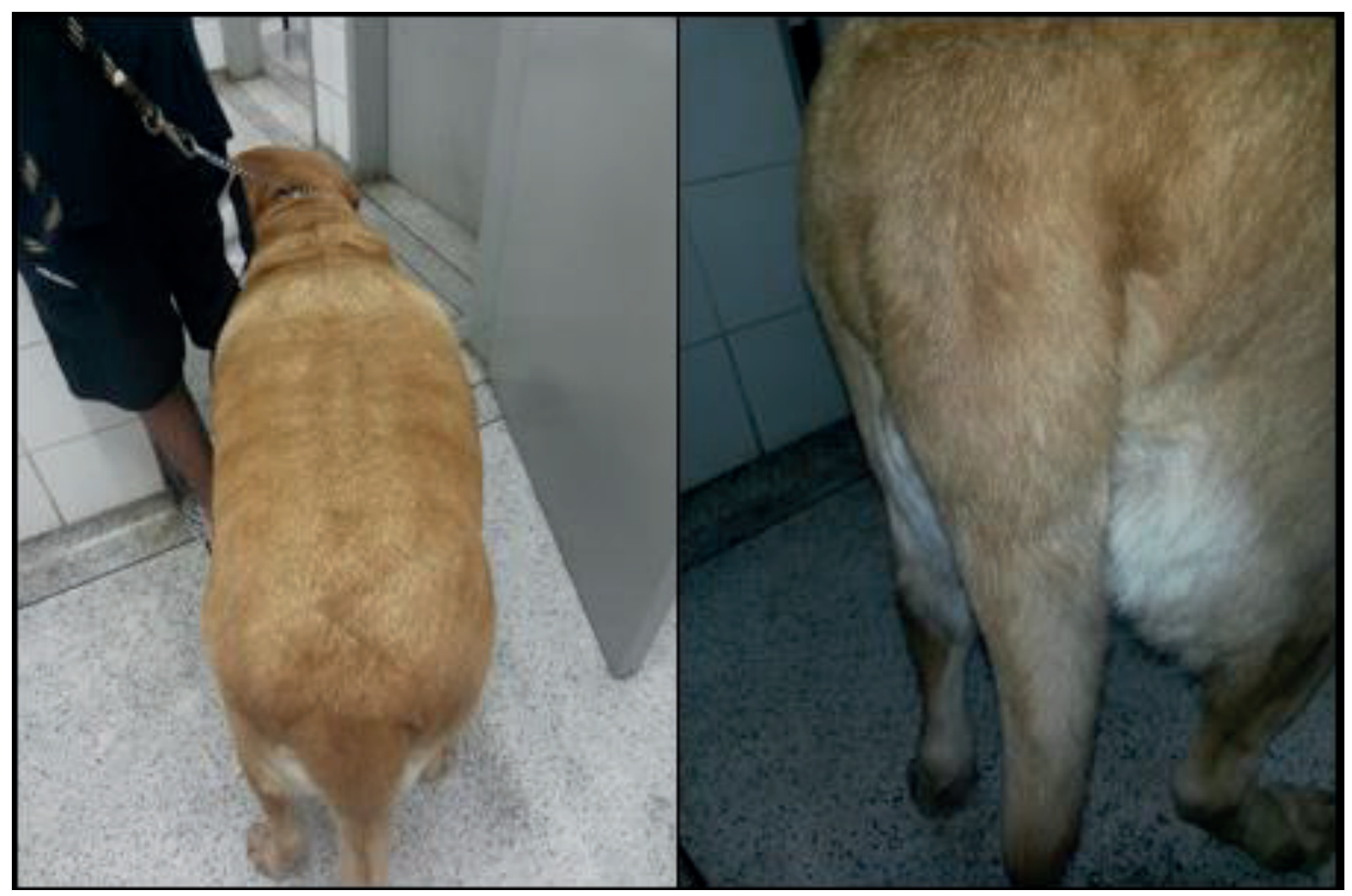

Figure 5. Body condition score in an obese Labrador retriever dog. The absence of a waist and the accumulation of adipose tissue in the dorsolateral trunk and base of the tail are noted. This animal was classified as score 9 (grade range: 1-9).

A 5-gradation system is also used (where 3 is considered ideal, 1 and 2 are indicative of malnutrition and 4 and 5 are indicative of overweight); however, this system has not been validated with DEXA, despite appearing to have good reproducibility in cats (Shoveller et al., 2014; Santarossa et al., 2017; Rollins \& Murphy, 2019).

The Size, Health, and Physical Evaluation (SHAPE) system is an evaluation system in which owners and veterinarians classify the animal's body condition score following information described in the method's algorithms. This system was designed to be applied even by untrained people, and its main advantage is its easy application at home, allowing the monitoring of the BCS of animals by their owners. A strong correlation between the SHAPE and DEXA was observed, similar to the correlation between DEXA and the 9-point BCS (Santarossa et al., 2017).

The main limitations of BCS methods include the subjectivity of the measure, the effect of shape variability between animal bodies of different breeds and the fact that the measure does not evaluate lean mass (Kathrani, 2016; Otsuji et al., 2016; Tarkosova et al., 2016; Michel, 2017). Moreover, the BCS only changes over the long term. No significant variations in BCS and mean weight were observed in dogs subjected to a $50 \%$ calorie restriction of their resting energy requirement for 14 days (Nakajima, Ohno, Goto-Koshino, Fujino, \& Tsujimoto, 2014).

One of the greatest uses of BCS is to set a goal for weight loss nutritional treatment (Laflamme, 1997a,b; Witzel et al., 2014a,b). Each unit of variation in the score (1-9 graduations) is associated 
with an average variation of $5 \%(3-9 \%)$ in the amount of adipose tissue and 10\% (5-15\%) in weight deviation, i.e., a $45 \mathrm{~kg}$ dog and 8 BCS would need to lose (on average) $15 \%$ of fat mass and 30\% of weight to achieve the optimal score (Laflamme, 1997a, 2012; Witzel et al., 2014a,b).

In addition, BCS can be used to monitor obesity treatment, select patients for nutritional support, and raise awareness among owners, illustrating to them the nutritional status of their animals (Laflamme, 1997a,b; Brooks et al., 2014; Koizumi et al., 2018). In one survey, $30 \%$ to $40 \%$ of overweight dog owners stated that their animals were in adequate body condition. However, when they were instructed about the BCS and its classification criteria, they agreed with the presence of obesity (White et al., 2011). The classification of NS with BCS facilitates this understanding (White et al., 2011; Koizumi et al., 2018).

Additionally, the BCS helps to infer the prognosis of patients, with deviations associated with increased morbidity and mortality (Elliott et al., 2010; Finn et al., 2010; Fabretti et al., 2014). Some researchers have found that low BCS values (especially 1 and 2 on the 9-point scale) are associated with high death rates in hospitalized dogs $(55.56 \%$ and $37.84 \%$, respectively) (Fabretti et al., 2014). Similar findings were observed in another survey (Brunetto et al., 2010). It should be kept in mind that even animals with normal or obese BCSs can be malnourished and have weight loss (Chandler \& Gunn-Moore, 2004).

\section{Other morphometric measures associated with fat mass measurement}

Although it is widely practiced in human medicine, objective measurements of body segments receive less attention in pets, especially in dogs, due to interbreed anatomical variations (Santarossa et al., 2017).

The measurements of the circumference (by tape measure) of the cranial thoracic region and the last rib have controversial results in cats with regard to the correlations with fat and muscle mass. In a study of cats, a positive correlation was observed between the pelvic circumference (PC) and fat mass, and a negative correlation with muscle mass was observed (Stanton, Hamar, Johnson, \& Fettman, 1992; Santarossa et al., 2017).

As a result of conflicting results with morphometry, more complex protocols were developed, such as the assessment of adipose mass in dogs by measuring the $\mathrm{CP}$ and the distance between the calcaneal tuberosity to the patellar ligament (DCTPL) (Burkholder, 1994; Elliott et al., 2010).

The formulas employed were (Mawby et al., 2004):

- Males: \% fat mass $=-1.4(\mathrm{DCTPL})+0.77(\mathrm{PC})$ +4 .

- Females: $\%$ fat mass $=-1.7($ DCTPL $)+0.93$ $(\mathrm{PC})+5$.

A protocol was also developed for cats based on the measurement of chest circumference (CT) in the ninth rib region and the leg measurement index (LMI), which describes the distance between the patella and the calcaneal tuberosity. The formula used was (Hawthorne \& Butterwick, 2000; Elliott et al., 2010):

$\bullet \%$ fat $\operatorname{mass}=(1.54 \times$ TC $)-(1.54 \times$ LMI $)-8.67$.

Another research group proposed an alternative formula for cats:

- $\%$ fat mass $=[($ TC / 0.7067 $)-$ LMI / 0.9156] LMI (Hawthorne \& Butterwick, 2000).

It is noteworthy that the ideal percentage of fat for dogs is between $15 \%$ and $20 \%$, and for cats, it is between 25-30\% (Michel, 2013; Brooks et al., 2014; Rollins \& Murphy, 2019).

A study that examined methods of determining NS in 50 cats found that estimation of \% fat mass by a mathematical formula was not useful for diagnosing obesity, as it had normal values in 
patients considered obese by the BCS (Aptekmann et al., 2014). In the authors' opinion, these methods are no more advantageous than the BCS.

\section{Muscle mass score (MMS)}

Muscle mass is associated with health status and the protein nutrition index. An animal may lose muscle mass due to disuse atrophy, neurogenic atrophy, senescence sarcopenia and malnutrition (common in the sick) (Freeman, 2012; Freeman, Michel, Zanghi, \& Boler, 2019). Disease-related muscle loss occurs rapidly and is an indicator of poor prognosis, so muscle mass assessment should be routinely performed throughout the consultation (Michel, 2015; Tarkosova et al., 2016; Freeman, 2012; Freeman et al., 2019).

The amount of muscle in a patient can be assessed by imaging exams such as ultrasound and computed tomography; however, such methods take time to perform and generate significant costs (Hutchinson, Sutherland-Smith, Watson, \&
Freeman, 2012; Freeman, 2012; Freeman et al., 2019). The MMS has the advantage of allowing this measurement immediately and for free (Baldwin et al., 2010; Freeman et al., 2011; World Small Animal Veterinary Association [WSAVA], 2013; Tarkosova et al., 2016).

Clinically, the BCS and MMS are not directly related (Baldwin et al., 2010; Freeman et al., 2011; Tarkosova et al., 2016). An animal may be overweight, with excess fat, but still have significant muscle loss; the excess fat can mask it, and the patient could appear normal if not carefully examined (Baldwin et al., 2010; Freeman et al., 2011; Tarkosova et al., 2016; Vandendriessche et al., 2017).

The MMS classification is performed by inspection and palpation on the musculature covering the bone prominences, mainly on the parietal region, scapula, pelvis and spine (mainly the lumbar region) (Figure 6) (Michel, Anderson, Cupp \& Laflamme, 2009, 2011; Freeman et al., 2011; WSAVA, 2013).

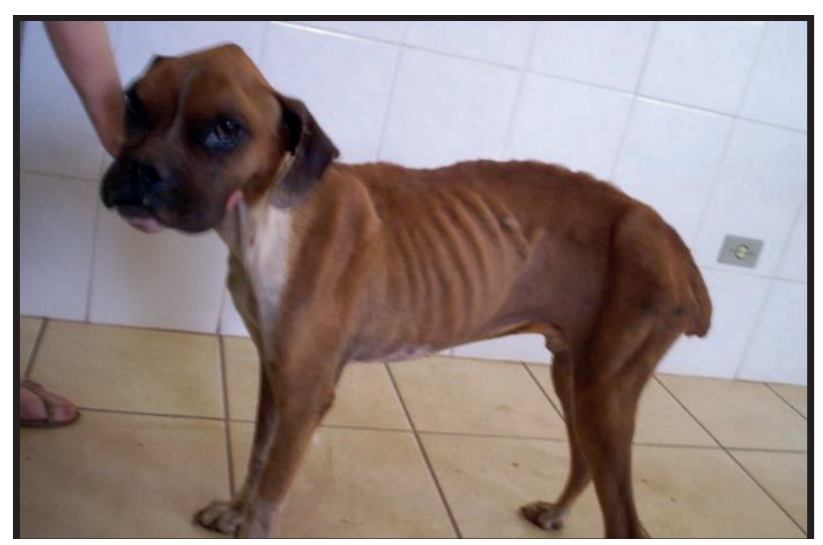

Figure 6. Muscle mass score in a boxer dog. There is an intense reduction in parietal, scapular and pelvic muscle mass. The consequence is that the bony prominences of these regions have become easily noticeable. This animal was classified as score 0 (score range: 0-3). 
The most commonly used grade was standardized in 2011 and defined four levels (0-3), 3 is considered normal and scores 2, 1 and 0 are used to describe muscle mass reduction intensities (Michel et al., 2009). Discrete muscle loss, which is only noticed by careful palpation of the aforementioned regions, is classified as MMS 2 as; in MMS 1 and 0 , the reduction also becomes apparent in the inspection due to the ease of observing bone prominences, with level 0 being distinguished by practically no palpable muscle mass in the indicated regions (Michel et al., 2009; Rollins \& Murphy, 2019).

A study of 44 cats found that the 4-point feline MMS has high repeatability and moderate to high reproducibility after 10 veterinarians evaluated the cats on three separate occasions (Michel et al., 2011). In dogs, MMS system has not yet been validated (Freeman, 2012; Santarossa et al., 2017; Freeman et al., 2019). However, a recent study of 40 dogs compared the assessment of MMS with data obtained from imaging tests, such as ultrasound, radiography and magnetic resonance imaging of the muscles. The authors concluded that the MMS has good repeatability and moderate reproducibility (Freeman et al., 2019).

The advantage of this determination is to evaluate the NS and prognosis; low MMS values indicate protein malnutrition. Regarding prognosis, patients with a low MMS are more likely to die because muscle loss is associated with immunodeficiency, weakness and lower healing capacity (Baldwin et al., 2010; Freeman et al., 2011; Corbee \& Kerkhoven, 2014). In one study, hospitalized dogs with various diseases and MMS of 1 and 2 had death rates of $50 \%$ and $53.85 \%$, respectively (Fabretti et al., 2014). Another study showed a mortality of $71 \%$ and $25 \%$ in dogs and cats with low MMS values, respectively (Vandendriessche et al., 2017). It is strongly recommended to jointly evaluate both the BCS and the MMS to obtain a reasonable estimate of the fat and muscular body composition.

\section{Skin and coat}

The skin is the largest organ in the body and is metabolically very active. Any excess or deficiency of nutrients can manifest in the skin and coat, although clinical changes are late, occurring after months. Opaque, scaly, alopecic or rough coats are suggestive of malnutrition (Roudebush \& Schoenherr, 2010).

Nevertheless, in some studies conducted with hospitalized dogs, the authors found no association of NS with the appearance of the skin and coat, concluding that they are not sensitive indicators NS (Fabretti et al., 2015).

\section{Conclusion}

Malnutrition is very common in sick animals, and its identification, monitoring and treatment are important for clinical improvement of the patient. Nevertheless, information on nutritional semiology is quite scarce in the specialized literature. The analysis of the information described in this article allows us to conclude that there are good signs of malnutrition in the anamnesis and clinical examination: the reduction of food intake for three days or more, weight loss, loss of fat or muscle mass (MMS below 3 and BCS below 4, using the grade 1-9 scale). The appearance of the skin and coat and the BMI are insensitive to the definition of NS. Regarding prognosis, the loss of fat mass, the loss of muscle mass or a significant reduction in BMI are indicators of poor clinical outcome.

\section{References}

Aptekmann, K. P., Mendes, A. F., Jr., Passo, C. B., Secchin, M. C., \& Galeas, M. A. V. (2014). Comparação dos diferentes métodos de avaliação corporal em felinos. Revista Brasileira de Medicina Veterinária, 36(2), 215-218.

Baldwin, K., Bartges, J., Buffington, T., Freeman, L. M., Grabow, M., Legred, J., \& Ostwald, J. D (2010). AAHA nutritional assessment guidelines for dogs and cats. Journal of the American Animal Hospital Association, 46(4), 285-296. doi: 10.5326/0460285 
Becvarova, I., Prochazka, D., Chandler, M. L., \& Meyer, H (2017). Nutrition education in European veterinary schools: are European veterinary graduates competent in nutrition? Journal of Veterinary Medical Education, 43(4), 349-358. doi: 10.3138/ jvme.0715-122R1

Bergler, R., Wechsung, S., Kienzle, E., Hoff, T., \& Dobenecker, B. (2016). Ernährungsberatung in der Kleintierpraxis - ein Arbeitsfeld für spezialisierte Tierärzte. Tierärztliche Praxis Kleintiere, 44(1), 5-14. doi: 10.1055/s-0037-1622399

Bjornvad, C. R., Nielsen, D. H., Armstrong, P. J., Mcevoy, F., Hoelmkjaer, K. M., Jensen, K. S.,... Kristensen, A. T. (2011). Evaluation of a ninepoint body condition scoring system in physically inactive pet cats. American Journal of Veterinary Research, 72(4), 33-37. doi: 10.2460/ajvr.72.4.433

Brooks, D., Churchill, J., Fein, K., Linder, D., Michel, K., Tudor, K.,... Witzel, A. (2014). 2014 AAHA weight management guidelines for dogs and cats. Journal of the American Animal Hospital Association, 50(1), 1-11. doi: 10.5326/JAAHA-MS-6331

Brunetto, M. A., \& Carcioffi, A. C. (2015). Suporte nutricional do paciente gravemente enfermo. In $\mathrm{M}$. M. Jericó, J. P. Andrade, Neto, \& M. M. Kogika (Eds.), Tratado de medicina interna de cães e gatos (Cap, 6, pp. 49-65). Rio de Janeiro, RJ: Editora Guanabara Koogan LTDA.

Brunetto, M. A., Gomes, M. O. S., Andre, M. R., Teshima, E., Gonçalves, K. N. V., Pereira, G. T.,... Carciofi, A. C. (2010). Effects of nutritional support on hospital outcome in dogs and cats. Journal of Veterinary Emergency and Critical Care, 20(2), 224-231. doi: 10.1111/j.1476-4431.2009.00507.x

Burkholder, W. J. (1994). Body composition of dogs determined by carcass composition analysis, deuterium oxide dilution, subjective and objective morphometry and bioelectrical impedance. Doctoral thesis, Virginia Polytechnic Institute and State University, Virginia, VA, United States of America.

Case, L., Daristotle, L., Hayek, M. G., \& Raasch, M. F. (2011). Energy and water. In L. Case, L. Daristotle, M. G. Hayek, \& M. F., Raasch (Eds.), Canine and feline nutrition: a resource for companion animal professionals (pp. 3-12). Missouri, MO: Mosby Elsevier.

Chandler, M. L., \& Gunn-Moore, D. A. (2004). Nutritional status of canine and feline patients admitted to a referral veterinary internal medicine service. Journal of Nutrition, 134(8), 2050-2052. doi: 10.1093/jn/134.8.2050S
Coe, J. B., O'Connor, R. E., MacMartin, C., Verbrugghe, A., \& Janke, K.A. (2020). Effects of three diets history questions on the amount of information gained from a sample of pet owers in Ontario, Canada. Journal of the American Veterinary Medical Association, 256(4), 469-478. doi: 10.2460/javma.256. 4.469

Corbee, R. J., \& Kerkhoven, W. J. S. V. (2014). Nutritional support of dogs and cats after surgery or illness. Journal of Veterinary Medicine, 4(4), 44-57. doi: 10.4236/ojvm.2014.44006

Delaney, S. J., \& Fascetti, A. (2006). Integration of nutrition into clinical practice. In P. Pibot, V. Biourge, \& D. Elliott (Eds.), Encyclopedia of canine clinical nutrition (Chap. 16, pp. 494-504). Aimargues: Aniwa SAS.

Eirmann, L. (2016). Nutritional assessment. Veterinary Clinics of North America: Small Animal Practice, 46(5), 855-867. doi: 10.1016/j.cvsm.2016.04.012

Elliott, D. A., Ettinger, S. J., \& Feldman, E. C. (2010). Body composition of the dog and cat. In S. J. Ettinger, \& E. C. Feldman (Eds.), Textbook of veterinary internal medicine expert consult (Chap. 165, pp.634637). California, CA: Elsevier.

Fabretti, A. K., Fonseca, I. B., Coelho, A. F., Silva, C. N., \& Pereira, P. M. (2015). Evaluation of clinical, laboratory, and electrophoretic profiles for diagnosis of malnutrition in hospitalized dogs. Semina: Ciências Agrárias, 36(1), 217-230. doi: $10.5433 / 1679-0359.2015 \mathrm{v} 36 \mathrm{n} 1 \mathrm{p} 217$

Fabretti, A. K., Fonseca, I. B., Pancieri, I. V. C., Knupp, F. C., Bordini, D. M., \& Pereira, P. M. (2014). Avaliação clínica, laboratorial e perfil eletroforético na determinação do prognóstico de cães hospitalizados. Semina: Ciências Agrárias, 35(6), 3113-3126. doi: 10.5433/1679-0359.2014v35n6 p3113

Fabretti, A. K., Siqueira, R. C. S., Chaves, R. O., Camacho, C. A., \& Pereira, P. M. (2018). Exames laboratoriais na desnutrição de pequenos animais. Revista Clínica Veterinária, 23(133), 40-54.

Finn, E., Freeman, L. M., Rush, J. E., \& Lee, Y. (2010). The relationship between body weight, body condition, and survival in cats with heart failure. Journal of Veterinary Internal Medicine, 24(6), 1369-1374. doi: 10.1111/j.1939-1676.2010.0584.x

Freeman, L. M. (2012). Cachexia and sarcopenia: emerging syndromes of importance in dogs and cats. Journal of Veterinary Internal Medicine, 26(1), 3-17. doi: 10.1111/j.1939-1676.2011.00838.x 
Freeman, L. M., Becvarova, I., Cave, N., Mackay, C., Nguyen, P., Rama, B.,.. Beukelen, P. V. (2011). World small animal veterinary association nutrional assesment guidelines. Journal of Small Animal Practice, 52(1), 385-396. doi: 10.1016/j. jfms.2011.05.009

Freeman, L. M., Michel, K. E., Zanghi, B. M., \& Boler, B. M. V. (2019). Evaluation of the use of muscle condition score and ultrasonographic measurements for assessment of muscle mass in dogs. American Journal of Veterinary Research, 80(6), 595-600. doi: 10.2460/ajvr.80.6.595

Gagne, J. W., \& Wakshlag, J. J. (2015). Pathophysiology and clinical approach to malnutrition in dogs and cats. In D. L. Chan (Ed.), Nutritional management of hospitalized small animals (pp. 117-127). Oxford, $\mathrm{OH}$ : John Wiley \& Sons.

Gama, F. F., Leite, M. A. S., Escodro, P. B., \& Notomi, M. K. (2016). Avaliação da condição corpórea em cães utilizando o índice de massa corpórea (IMC) e escore de condição corpórea (ECC). Ciência Veterinária nos Trópicos, 19(2), 19-25.

Hawthorne, A. J., \& Butterwick, R. F. (2000). Predicting the body composition of cats: development of a zoometric measurement for estimation of percentage body fat in cats. Journal of Veterinary Internal Medicine, 14(3), 365-375.

Hesbach, A. L. (2007). Techniques for objective outcome assessment. Clinical Techniques in Small Animal Practice, 22(3), 146-154. doi: 10.1053/j. ctsap.2007.09.002

Hutchinson, D., Sutherland-Smith, J., Watson, A. L., \& Freeman, L. M. (2012). Assessment of methods of evaluating sarcopenia in old dogs. American Journal of Veterinary Research, 73(11), 1794-1800. doi: 10.2460/ajvr.73.11.1794

Johnson, L. N., \& Freeman, L. M. (2017). Recognizing, describing, and managing reduced food intake in dogs and cats. Journal of the American Veterinary Medical Association, 251(11), 1260-1266. doi: 10.2460/javma.251.11.1260

Kanda, T., Maeta, N., Iguchi, A., Shibata, K., Nomura, C., Yamamoto, T.,... Furukawa, T. (2013). Correlation between computed tomographic assessment of body fat and body condition score evaluation in dogs. Journal of Pet Animal Nutrition, 16(1), 1-6. doi: 10.11266/jpan.16.1

Kathrani, A. (2016). Nutritional support in the intensive care unit. In Practice, 38(4), 18-24. doi: 10.1136/inp. i5414
Kawasumi, K., Iwazaki, E., Okada, Y., \& Arai, T. (2016). Effectiveness of feline body mass index (fBMI) as new diagnostic tool for obesity. Japanese Journal of Veterinary Research, 64(1), 51-56. doi: 10.14943/ jjvr.64.1.51

Koizumi, A., Aoyama, K., Morishita, M., Sugiyama, Y., \& Otsuji, K. (2018). The effectiveness of the body condition score model for the nutritional assessment in dogs (the 2nd report). Jornal da Sociedade da Nutrição do Animal de Estimação, 21(2), 95-101. doi: 10.11266/jpan.21.2_95

Laflamme, D. P. (1997a). Development and validation of a body condition score system for dogs. Canine Practice, 22(4), 10-15.

Laflamme, D. P. (1997b). Development and validation of a body condition score system for cats: a clinical tool. Feline Practice, 25(5), 13-18.

Laflamme, D. P. (2012). Companion animals symposium, obesity in dogs and cats: what is wrong with being fat? Journal of Animal Science, 90(7), 1653-1662. doi: $10.2527 /$ jas.2011-4571

Liu, D. T., Brown, D. C., \& Silverstein, D. C. (2012). Early nutritional support is associated with decreased length of hospitalization in dogs with septic peritonitis: a retrospective study of 45 cases (2000-2009). Journal of Veterinary Emergency and Critical Care, 22(4), 453-459. doi: 10.1111/j.14764431.2012. 00771.x

Macmartin, C., Wheat, H. C., Coe, J. B., \& Adams, C. L. (2015). Effect of questions design on dietary information solicited during veterinarian-client interactions in companion animal practice in Ontario, Canada. Journal of the American Veterinary Medical Association, 246(11), 1203-1214. doi: 10.2460/ javma.246.11.1203

Maicá, A. O., \& Schweigert, I. D. (2008). Avaliação nutricional em pacientes graves. Revista Brasileira de Terapia Intensiva, 20(3), 286-295.

Mauldin, G. E., \& Davidson, J. R. (2007). Suporte nutricional em cães e gatos hospitalizados. In D. Slatter (Ed.), Manual de cirurgia de pequenos animais (pp. 87-91). Barueri, SP: Manole.

Mawby, D. I., Bartges, J. W., d'Avignon, A., Laflamme, D. P., Moyers, T. D., \& Cottrell, T. (2004). Comparison of various methods for estimating body fat in dogs. Journal of the American Animal Hospital Association, 40(2), 109-114. doi: 10.5326/0400109

Michel, K. E. (2017). Nutritional assessment . In S. J. Ettinger, \& E. C. Feldman (Eds.), Textbook of veterinary internal medicine expert consult (Chap. 170, pp. 1830-1833). California, CA: Elsevier. 
Michel, K. E. (2009). Using a diet history to improve adherence to dietary recommendations. Compendium: Continuing Education for Veterinarians, 18(31), 2224.

Michel, K. E. (2013). Nutritional management of body weight. In A. J. Fascetti, \& S. J. Delaney (Eds.), Applied veterinary clinical nutrition (Chap. 9, pp. 109-124). California, CA: John Wiley \& Sons.

Michel, K. E. (2015). Nutritional assessment in small animals. In D. L. Chan (Ed.), Nutritional management of hospitalized small animals (pp. 1-6). Oxford, $\mathrm{OH}$ : John Wiley \& Sons.

Michel, K. E., Anderson, W., Cupp, C., \& Laflamme, D. (2009). Validation of a subjective muscle mass scoring system for cats. Journal of Animal Physiology and Animal Nutrition, 93(6), 806. doi: 10.1017/S000711451100050X

Michel, K. E., Anderson, W., Cupp, C., \& Laflamme, D. P. (2011). Correlation of a feline muscle mass score with body composition determined by dual-energy x-ray absorptiometry. British Journal of Nutrition, 106, 57-59. doi: 10.1017/S000711451100050X

Mohr, A. J., Leisewitz, A. L., Jacobson, L. S., Steiner, J. M., Ruaux, C. G., \& Williams, D. A. (2003). Effects of early enteral nutrition on intestinal permeability, intestinal protein loss, and outcome in dogs with severe parvoviral enteritis. Journal of Veterinary Internal Medicine, 17(6), 791-798. doi: 10.1111/ j.1939-1676.2003.tb02516.x

Muller, J. E., Pinheiro, M. S., \& Mendonça, D. C. (2008). Adaptação do índice de massa corporal humano para cães. Ciência Rural, 38(4), 1038-1043. doi: 10.1590/ S0103-84782008000400020

Nakajima, M., Ohno, K., Goto-Koshino, Y., Fujino, Y., \& Tsujimoto, H. (2014). Plasma transferrin concentration as a nutritional marker in malnourished dogs with nutritional treatment. The Journal of Veterinary Medical Science, 76(4), 539-543. doi: 10.1292/jvms. 13-0583

Otsuji, K., Koizumi, A., Kobayashi, N., Suzuki, M., Furukawa, N., Kumira, A., \& Kobayashi, T. (2016). The effectiveness of the body condition score model for the nutritional assessment in dogs. Pet Nutrition Society Journal, 19(1), 15-20. doi: 10.11266/ jpan.19.1_15

Purina (2016). Formulário de histórico alimentar. In Nestle Purina Petcare, Nutrição clínica canina $e$ felina: guia prático de referência para uso diário no exercício da medicina veterinária (pp. 125-126). São Paulo, SP: Nestlé Purina.
Rollins, A. W., \& Murphy, M. (2019). Nutritional assessment in the cat practical recommendations for better medical care. Journal of Feline Medicine and Surgery, 21(5), 442-448. doi: 10.1177/1098612X 19843213

Romano, F. R., Heinze, C. R., Barber, L. G., Mason, J. B., \& Freeman, L. M. (2016). Association between body condition score and cancer prognosis in dogs with Lymphoma and Osteosarcoma. Journal of Veterinary Internal Medicine, 30(4), 1179-1186. doi: 10.1111/ jvim. 13965

Rosa, K. A., Fabretti, A. K., Zanutto, M. S., \& Chaves, R. O. (2014). Efeitos da alimentação hipossódica em cães cardiopatas. MEDVEP - Revista Científica de Medicina Veterinária, 12(42), 462-467.

Roudebush, P., \& Schoenherr, W. D. (2010). Skin and hair disorders. In M. S. Hand, C. D. Tratcher, R. L. Remillard, P. Roudebush, \& C. Novotny (Eds.), Small animal clinical nutrition (pp. 637-665). Topeka, KS: Mark Morris Institute.

Saker, K. E., \& Remillard, R. L. (2010). Critical care nutrition and enteral-assisted feeding. In M. S. Hand, C. D. Tratcher, R. L. Remillard, P. Roudebush, \& C. Novotny (Eds.), Small animal clinical nutrition (pp. 351-390). Topeka, KS: Mark Morris Institute.

Santarossa, A., Parr, J. M., \& Verbrugghe, A. (2017). The importance of assessing body composition of dogs and cats and methods available for use in clinical practice. Journal of the American Veterinary Medical Association, 251(5), 521-529. doi: 10.2460/ javma.251.5.521

Shoveller, A. K., Digennaro, J., Lanman, C., \& Spangler, D. (2014). Trained vs untrained evaluator assessment of body condition score as a predictor of percent body fat in adult cats. Journal of Feline Medicine and Surgery, 16(12), 957-965. doi: $10.1177 / 1098612$ X14527472

Stanton, C. A., Hamar, D. W., Johnson, D. E., \& Fettman, M. J. (1992). Bioelectrical impedance and zoometry for body composition analysis in domestic cats. American Journal of Veterinary Research, 53(2), 251-257.

Tarkosova, D., Story, M. M., Rand, J. S., \& Svoboda, M. (2016). Feline obesity - prevalence, risk factors, pathogenesis, associated conditions and assessment. Veterinarni Medicina, 61(6), 295-307. doi: 10.17221/145/2015-VETMED

Vandendriessche, V. L., Picavet, P., \& Hesta, M. (2017). First detailed nutritional survey in a referral companion animal population. Journal of animal 
physiology and animal nutrition, 101(1), 4-14. doi: 10.1111/jpn. 12621

Veado, J. C. C. (2015). Nutrição clínica do paciente hospitalizado: nutrição parenteral e enteral. In M. M. Jericó, J. P. Andrade, Neto, \& M. M. Kogika, Tratado de medicina interna de cães e gatos (Cap. 37, pp. 291-298). Rio de Janeiro, RJ: Editora Guanabara Koogan LTDA.

White, G. A., Hobson-Wes,T. P., Cobb, K., Craigon, J., Hammond, R., \& Millar, K. M. (2011). Canine obesity: is there a difference between veterinarian and owner perception? Journal of Small Animal Practice, 52(12), 622-626. doi: 10.1111/j.17485827.2011.01138.x

Witzel, A. L., Kirk, C., Henry, G., Toll, P. W., Brejda, J. J., \& Paetau-Robinson, I. (2014a). Use of a morphometric method and body fat index system for estimation of body composition in overweight and obese dogs. Journal of the American Veterinary Medical Association, 244(11), 1279-1284. doi: 10.2460/javma.244.11.1279
Witzel, A. L., Kirk, C., Henry, G., Toll, P. W., Brejda, J. J., \& Paetau-Robinson, I. (2014b). Use of a morphometric method and body fat index system for estimation of body composition in overweight and obese cats. Journal of the American Veterinary Medical Association, 244(11), 1285-1290. doi: 10.2460/javma.244.11.1285

World Small Animal Veterinary Association (2013). Muscle condition score. Ontario, CA: WSAVA Global Veterinary Development. Retrieved from https://www.wsava.org/WSAVA/media/Documents/ Committee\%20Resources/Global\%20Nutrition\%20 Committee/Muscle-condition-score-chart-2013-1.pdf 